Jaroslav David

\title{
DELIMITATIVE FUNCTION OF PLACE NAMES IN THE LINGUISTIC \\ LANDSCAPE - AS ILLUSTRATED \\ WITH EXAMPLES FROM THE CITIES \\ OF PRAGUE AND OSTRAVA \\ (CZECH REPUBLIC)
}

\begin{abstract}
The paper is focused on the spatial appearance of two place names in the public space in the background of the transonymization process; there are the Czech place names of Andel ('Angel'; a busy crossroads, Prague) and Kuři rynek ('Chicken Market'; a small square, Ostrava). The paper attempts to provide answers to the following research questions: 1) Is there any mutual relationship between the places delimitation and the place names occurrence? 2) In which forms and for which objects are the namings used? 3) Do the areas delimited by the place names representation in the public space, and those mentally perceived by people living there overlap?
\end{abstract}

\section{KEYWORDS}

place names; transonymization; linguistic landscape; delimititative function

\section{Introduction}

The aim of the text is to examine two place names spatial appearance in the public space in the background of the transonymization process; there are the place names of Anděl (a busy crossroad, Prague) and Kuř́ rynek (a small square, Ostrava, both the Czech Republic). There are analysed chrematonyms (namings of shops, 
pubs, etc.) based on the place names forms; the data were collected through a field survey carried out during May and June 2018 in the localities. The paper goal is to get answers on the following research questions: 1) Is there any mutual relationship between the places area delimitation and the place names occurrence in the urban public space? 2) In which forms and for which objects are the de-toponymic namings used? 3) Do the areas delimited by the place names representation in the public space, and those mentally perceived by people living there overlap?

\section{The transonymization process}

Place names are the substantial and integral part of the linguistic landscape, in the way the concept was formulated in the cornerstone study by Landry and Bourhis (1997, 25): “... the language of public road signs, advertising billboards, street names, place names, commercial shop signs, and public signs on government buildings." During the previous two decades, the concept has been elaborated as part of spatial studies, and nowadays, it has become fully accepted in Czech geography and social sciences - and in linguistics, too, mostly in urban place names research (cf. DAVID MÁCHA 2014; DAVID 2016). In the public space, place names are mostly represented in a written form. They appear on road, street, and city transport stop signs, and they are also included in pub, shop, hotel, and company names, and in namings of residential and office buildings or premises. Therefore, the concept of linguistic landscape is sometimes rectified, and the notions of written-text landscape / scriptorial landscape are used instead (GADE 2003, 430-431; DAVID - MÁcHA 2014). In the perspective of place names research, the notion of the toponymic landscape is used, too.

The basic function of a place name is to refer to a particular object; through its place name, the object is identified as a unique element and it is concurrently differed from the others (ŠRÁMEK 1999, 22-26). Very often, the unique name manifests a strong potential to be transferred to name another object - e.g., the original name refers to an extraordinary geographical object, or a unique event or circumstances connected with it. In such a situation, the original name is used for naming another object because of their similarity, mutual relationship, or spatial proximity; the process is known as transonymization (ŠRÁMEK 2003-2004; PLESKALOVÁ 2017). However, the transonymization process does not take place only between two objects, the original one and the newly named one. Frequently, a place name with high naming potential is transferred several times to name different objects. For instance, the Italian city name Venezia (Venice in English), or rather its Czech form Benátky, was transferred, mostly during the Middle Ages, to name several cities, villages, and a lot of marsh areas (field names) in the Czech Lands (DAvid - Rous 2006, 31-32; MATÚŠOvÁ 2007; KoMÁRKOvÁ 2019). The Italian city has always been admired as the city built "on water", and interwoven with water canals; Czech plac- 
es were named metaphorically because of their connection with water and marshy land. In modern times, it is also the original Italian form - Venezia - that is used (the same as Roma, Toscana, Modena) for naming Czech pizzerias and restaurants offering Italian specialities; in the background of the name giving, there is a stereotype based on relationship between the traditional meal, the country, and the original language form, as well as the marketing purpose. The example of the Venezia / Benátky place name illustrates the fact that the process of transonymization comprises many specific sub-processes, put into practice in different time periods, using different forms of place names, and transferring place names not only within a group of geographical objects, but also beyond its border.

If one focuses on a particular place name spreading from the spatial and temporal perspectives, the multi-transonymization process can be regarded as the expression of the information / spatial / value distribution represented by the original place name; a spatial appearance of a particular name caused by the transonymization process creates a visible border of the area connected with a particular value. For instance - using another example taken from exonymy - a spatial distribution of the Amerika (America) place names in the Czech Lands, mostly naming natural objects - e.g., fields, meadows, pasture lands, hills, woods, as well as solitary houses, and pubs - closely corresponds with the intensity of emigration from the Czech Lands - and from the particular regions - to America, predominantly to the United States, in the course of the 19th and the first half of the 2oth centuries. The place name Amerika is used for naming places far away from the settlement, or places bearing a similarity to America, mostly to the United States - wild natural scenery, corn growing, architectural style of a building -, as was known from the eyewitness accounts, or newspapers, fiction books, and movies (Olivová-NeZBedová 2005; DAVID -Rous 2006, 29-30; ŠRÁMEK 2019).

\section{Case studies - the place names of Anděl and Kuří rynek}

\subsection{The survey methodology}

The following text is focused on two particular research cases when unofficial (non-standardized) city place names appearing within chrematonymy (names of companies, shops, restaurants, hotels, etc.) determine the boundaries of the area bearing a particular place name (cf. LÁBUS - VRBík 2018, the research aimed at object fixation of toponyms and its visualization by GIS mapping tools). They are the place names of Anděl (Prague) and Kuř́ / Kuři rynek ${ }^{1}$ (Ostrava). During May and June 2018, I did my field survey in the Smíchov (Prague) and Moravská Ostrava (Ostrava) districts. I walked through the local streets to gather all publicly presented proper

1 The form Kuři rynek with a short pronunciation, i.e. without vowel quantity, is mostly typical of a local spoken dialect; in the text, the (standard) form Kuři rynek is used. 
names based on the place names Anděl and Kuří rynek; there are mostly names of pubs and restaurants, shops, and multifunctional urban objects. The goal of my survey was to collect these names; I documented them via photos, and at the same time, their occurrences were marked on the maps (Map 1 and 2) to delimit the areas that are covered by the names of Anděl and Kuř́ rynek. Another step was to do a brief survey through questionnaires to collect the data on the places delimitation from the local people living in the city districts. It was realized during September and October 2018. The questionnaire asked respondents about the examined localities (20 people in Prague, 18 in Ostrava); the questions were designed to get information on the areas spatial delimitations and perceptions. The data were then compared with a particular place name spreading, i.e., chrematonyms using the place name forms.

\subsection{Case study- the place name of Anděl (Prague)}

The place name of Andell refers to a busy crossroads in the Smíchov district, a wider city centre of Prague, the capital city of the Czech Republic. The place name was inspired by the house name U Zlatého andéla ('At the Golden Angel'). The house was built in 1850 , and during the 1870 s, a local brewery and pub were joined to it. The frontage of the house was decorated with the painting displaying an angel wearing wavy clothes. A hundred and thirty years later, in the early 1980s, the building was demolished to pave the way for the Prague metro (underground) station (JuNGMANN 2007, 48-52). The underground station was open in 1985, and until 1990, its name was Moskevská ('the City of Moscow Station'); at the period, a local tram stop carried the same name Moskevská as well. After the fall of Communism in 1989 (the Velvet Revolution), the original name of the place, Anděl, was given back to the underground station and tram stop (FoJTík 2011, 132). In 2000, the modern shopping and administrative centre named Zlatý anděl ('the Golden Angel') was opened in the place of the gone house; the modern building with a huge angel silhouette on a glass facade was designed by French architect Jean Nouvel.

In the area of Smíchov, I collected 20 names referring to 20 objects (Table 1). There are 8 names of shops and services - a funeral service included -, 5 names of pubs, restaurants, and bars, 4 names of business-administrative centres, and 3 names of hotels and residential buildings; the city transport stop signs are not included. 
Table 1 Chrematonyms referring to the place name Anděl (Prague). Names are presented in original spelling forms.

\begin{tabular}{|c|c|c|}
\hline Chrematonym & Named object & Locality \\
\hline ZLATNICTVÍ U ANDĚLA & jeweller's & Bozděchova Street \\
\hline ANDĚL PARK & business-administrative centre & Radlická Street \\
\hline angelo HOTEL & hotel & Radlická Street \\
\hline palác anděl & business-administrative centre & Radlická Street \\
\hline Anděl City & business-administrative centre & $\begin{array}{c}\text { Stroupežnického } \\
\text { Street }\end{array}$ \\
\hline andel's HOTEL PRAGUE & hotel & $\begin{array}{c}\text { Stroupežnického } \\
\text { Street }\end{array}$ \\
\hline SUNANGEL & tanning salon & $\begin{array}{c}\text { Stroupežnického } \\
\text { Street }\end{array}$ \\
\hline $\begin{array}{c}\text { Andel's KADEŘNICKÉ } \\
\text { STUDIO }\end{array}$ & hairdressing salon & $\begin{array}{c}\text { Stroupežnického } \\
\text { Street }\end{array}$ \\
\hline ZLATÝ ANDĚL & business-administrative centre & Nádražní Street \\
\hline ANDĚL BAR & bar & Štefánikova Street \\
\hline $\begin{array}{c}\text { CENTRUM } \\
\text { FYZIOTERAPIE ANDĚL }\end{array}$ & physiotherapy centre & Štefánikova Street \\
\hline Optika Anděl & optician's & Štefánikova Street \\
\hline $\begin{array}{l}\text { ČÍNSKÁ RESTAURACE } \\
\text { ANDĚLSKÝ ÚJEZD / } \\
\text { CHINESE RESTAURANT } \\
\text { ANGEL PROVINCE }\end{array}$ & restaurant & $\begin{array}{c}\text { Arbesovo náměstí } \\
\text { Square }\end{array}$ \\
\hline mozzarellart Anděl & foodshop & Preslova Street \\
\hline $\begin{array}{c}\text { POHŘEBNÍ SLUŽBA } \\
\text { NA ANDĚLU }\end{array}$ & funeral service & Na Bělidle Street \\
\hline CAFE ANGEL WINN BAR & bar & Na Bělidle Street \\
\hline $\begin{array}{c}\text { Anděl APARTMENTS } \\
\text { PRAHA }\end{array}$ & apartments accommodation & Nádražní Street \\
\hline KLINIKA KRÁSY ANDĚL & beautician's & Nádražní Street \\
\hline PIVNICE U ANDĚLA & restaurant & Lidická Street \\
\hline $\begin{array}{c}\text { Restaurant El Barrio de } \\
\text { Ángel }\end{array}$ & restaurant & Lidická Street \\
\hline
\end{tabular}

Linguistically, they are two points of views that can be adopted. The first perspective is the language that is used, the second one is the morphological structure of the names - which is important, given the main goal of the paper.

From the first perspective, the chrematonyms split into two groups. There are prevailing Czech language forms (14) based on the Anděl name form, including the 
Delimitative Function of Place Names in the Linguistic Landscape - as Illustrated with Examples ...

mixed Czech-English form ČÍNSKÁ RESTAURACE ANDĚLSKÝ ÚJEZD / CHINESE RESTAURANT ANGEL PROVINCE, referring to the same object; foreign language forms (7 appearances, the mixed form mentioned above is also included) are represented by the names based on A/angel, Ángel, and Angelo, and the form of andel - i.e., original Czech form without Czech diacritical marks - as well.

Concerning the morphological structure of the names, there are also two types of forms. The prevailing type is the one that uses - regardless of the language - the basic place name form (the Czech, or the foreign, adapted one) and integrates it into the chrematonyms. The second type - only 2 pieces of evidence (POHŘEBNÍ SLUŽBA NA ANDĚLU, PIVNICE U ANDĚLA) - is represented by the names that use the basic form of a place name with a place preposition: $n a$ ('at the place of'), and $u$ ('close to the place'). Despite their forms, they have to be interpreted in the same way as the first ones: although they use the place name Andell with the spatial prepositions regardless of their origin and inspiration -, they convey the information that the named object is situated in the area of the crossroads of Andél and its immediate surroundings. Therefore, those two name forms are also included in further analysis corpus of the study; they refer to the very centre of the locality.

If the chrematonyms are put into the map, the delimitation of the Andel area is visible as it is marked in the public space (Maps 1 and 2). The area borders are created by the busy streets of Radlická in the west, Ostrovského and Vltavská in the south, Zborovská in the east, and V Botanice and Kartouzská (streets) in the north. In the north, in the west, and in the south, the area is also delimited with other place-name areas the names of which - in both standardized, and in non-standardized forms - are presented in the public space. There are place names of Arbes / Arbesák (a shortened form of Arbesovo náměstí - 'Arbes Square' -, named after Czech writer and journalist Jakub Arbes, 1840-1914) and Na Knížecí ('In the Prince's Road'; the name of a local bus station); both names are represented in the public space in many forms, e.g., names of stops, shops, pubs. The sharp border is delimited on the line of the Štefánikova street, connecting the crossroads of Anděl and the Arbesovo náměstí square.

There are two unique spatial situations where two chrematonyms referring to the different districts / areas meet: 1) the Anděl optician's (Optika Anděl) and the Arbes hotel (Hotel Arbes) on the corner of Victora Huga and Štefánikova streets; 2) the Arbes squash and fitness centre (Squash a fitness centrum Arbes) and the bilingual restaurant name ČÍNSKÁ RESTAURACE ANDĚLSKÝ ÚJEZD / CHINESE RESTAURANT ANGEL PROVINCE - both situated on and below of the Arbesovo náměstí square, at the same block. The latter is presented in the Czech and English forms, but the expression Angel Province is neither a literal, nor even approximate translation of ANDĚLSKÝ ÚJEZD (újezd means a specific form of mediaeval settlement, i.e., 'a district a rider goes around in one day'; in the treated situation, the chrematonym refers to the name of the district of Ujezd in the neighbourhood of the Arbesovo náměstí square). The 
uniqueness of the situation lies in two facts. First, there is a short distance between the name signs on the area border - the border between areas named by a particular name is thus visible in the public space; second, the ANDĚLSKÝ UJEZD Chinese restaurant, as I got to know through an email interview with the owner, was named because of its location on the border between the Anděl and Újezd areas. ${ }^{2}$

\subsection{Case study - the place name of Kuří rynek (Ostrava)}

The second example is taken from the centre of the city of Ostrava, the third largest city in the Czech Republic, which is situated on the border with Slovakia and Poland. Near the main city square, dedicated to the first Czechoslovak president, Tomáš Garrigue Masaryk (Masarykovo náměstí), there is a small area officially known as Jiráskovo náměstí ('Jirásek Square'). This was created at the beginning of the 2oth century after several house demolitions. Originally, it carried the name Kaiser Franz Josef Platz ('Emperor Franz Joseph Square'); after the creation of the Czechoslovak Republic, it was renamed to Jiráskovo náměstí, after the Czech writer Alois Jirásek (1851-1930). From the very beginning, the place has been unofficially called Kuř́ rynek ('Chicken Market') because of its main purpose (AdAmus 1934, 69); this name has been used in colloquial communication, and also appeared in official documents and advertisement until now (DAvid - MÁcHA 2014, 78-80). The name refers to one of the most important city points in the Ostrava centre. Here, it has to be mentioned that although the colloquial form is Kuři rynek, neither of the collected chrematonyms (Table 2) uses the full form of the name; it is the $R$ / rynek ('M/market') that appears only. I am aware of the fact it is not possible to say definitely if in case of the chrematonyms, the part of the colloquial place name is included (i.e., the form R/rynek instead of Kuř́ rynek), or whether it is an appellative naming for the space - a small, not large square, a form synonymous with the expressions náměstíćko or malé náměstí ('small square'). However, the short form $R$ / rynek is not used in colloquial communication for naming the place - and this is the reason I have decided for the first interpretation; the form $R / r y n e k$ is thus regarded as the part of the colloquial place name.

In June 2018, during a field research, I got 5 chrematonyms using the aforementioned non-standardized place name (Table 2).

2 See a section from an e-mail answer from 25th June 2018: "You are right, we are situated on the border between the Anděl and Újezd districts; therefore, the name of Andělský Újezd was chosen. Thank you. Best regards Hanka Ji". 
Delimitative Function of Place Names in the Linguistic Landscape - as Illustrated with Examples ...

Table 2 Chrematonyms referring to the place name Kuři rynek (officially, Jiráskovo náměstí; Ostrava). Names are presented in their original spelling forms.

\begin{tabular}{|c|c|c|}
\hline Chrematonym & Named Object & Locality \\
\hline RYBÁRNA na rynku & fish restaurant & Jiráskovo náměstí \\
\hline shisha bar NA RYNKU & bar & Jiráskovo náměstí \\
\hline Čajovna na Rynku & tearoom & Jiráskovo náměstí \\
\hline Obchod na rynku & cell phone shop & Jiráskovo náměstí \\
\hline ANTIKVARIÁT U RYNKU & secondhand bookshop & Poštovní street \\
\hline
\end{tabular}

Given the spatial distribution of the name through the appearance of the local chrematonyms and the field research data, the area of the square unofficially known as Kuř́ rynek is sharply delimited and perceived by the local people. The place name of Kuř́ rynek is understood solely within the area of the small square place. This fact stems from the delimited form of the square, and from the appellative semantics of the rynek name - although it is an old-fashioned expression for a city or village square, it is still fully understandable, and even used in standardized Czech urbanonymy (cf. street names Na Rynku in Kunovice, Kněžmost, and Praha, Rynek in Stará Ves nad Ondřejnicí, Ryneček in Př́ibram), as well as in non-standardized one (cf. names Ryneček - officially náměstí Svobody square in Jičín, Ryneček - Masarykova street in Častolovice). The fact is also illustrated with the usage of the name Na Rynku in chrematonyms referring to the objects (bars, restaurants, a shop) situated only on the square. If the object is situated out of the square area, i.e. ANTIKVARIÁT U RYNKU, then its name refers to the position outside ( $u$ 'close to the place').

\section{Conclusions}

The research has confirmed that the appearance of the place names in the public space is an important factor in preserving the current referential relationship between the name and the object. However, because of the different interests of public actors sharing the public landscape and participating in its creation, it is obvious the spatial performance of the names is various and depends on many factors. This fact was illustrated with two research probes. In case of the Andell place name (Prague), the area of its visual presentation is wider than its real object reference, according to the questionnaire research; the areas are not overlapping. The reason behind this discrepancy is that even the extraordinary, but still semantically clear naming Anděl ('an angel'), is used in name of pubs and hotels - it becomes a part of chrematonyms. Its high naming potential, from the marketing perspective, is given by its international comprehensibility, positive connotations, as well as the possibility to be transformed for commercial naming purposes (Table 1). 
In case of the Kuři rynek square name (Ostrava), the place name reference object and the area of chrematonyms making use of the name are completely overlapping. The fact is explained by the name form that comprises an appellative element rynek ('a square'). The appellative naming determines the referential object in case of the place name and in case of chrematonyms as well - i.e., the chrematonyms with the rynek element, namely in form na rynku ('at the square'), are not allowed to refer to the object outside the square.

The examined examples have shown the usage of the place name in different communicative contexts; here, place names were used in chrematonyms, this fact having an influence on their referential extent and areas.

\section{REFERENCES}

AdAmus, Alois. 1934. Legendy ostravských ulic [Stories of Street Names of the City of Ostrava]. Ostrava: Nákladem města Moravské Ostravy.

DAviD, Jaroslav. 2016. Toponymie městského prostoru v kontextu mezioborovosti české onomastiky - kritické poznámky a perspektiva dalšího výzkumu [Toponymy of the Urban Area in the Context of Interdisciplinary Approaches to Czech Onomastic Research - Critical Remarks and Perspectives of Further Research]. Studie z aplikované lingvistiky 7, 39-54.

DAvid, Jaroslav - MáchA, Přemysl. 2014. Názvy míst: pamět', identita, kulturní dědictví [Place Names - Memory, Identity, Cultural Heritage]. Brno: Ostravská univerzita - Host.

David, Jaroslav - Rous, Pavel. 2006. Neviditelní svědkové minulosti: místní a pomístní jména na Vysočině [Invisible Witnesses of the Past: Settlement and Natural Place Names in the Vysočina Region]. Praha: Academia.

FojTík, Pavel. 2011. Tramvaje a tramvajové tratě 2. Historická předměstí a obce na levém břehu Vltavy [Tramways and Tramways Lines 2. Historical Suburbs and City Parts Situated on the Vltava River Left Bank]. Litomyšl - Praha: Paseka - Schola Ludus - Pragensia.

GADE, Daniel W. 2003. Language, Identity, and the Scriptorial Landscape in Québec and Catalonia. Geographical Review 93(4), 429-448.

JungmanN, Jan. 2007. Smíchov. Město za Újezdskou branou [Smíchov. The City behind the Gate of the District of Újezd]. Praha: Muzeum hlavního města Prahy.

Komárková, Zina. 2019. Benátka / Benátky [Benátka / Benátky 'Venice Place Name’]. In: Slovník pomistních jmen na Moravě a ve Slezsku [online]. Brno: dialektologické oddělení Ústavu pro jazyk český AV ČR, v. v. i. 2014 [Retrieved 2019-01-31]. Available at http://spjms. ujc.cas.cz

LÁBUS, Václav - VRBíK, Daniel. 2018. Toponyma v krajině a možnosti jejich výzkumu [Toponyms in Landscape: Options of Research]. Liberec: Technická univerzita v Liberci.

LANDRY, Rodrigue - BOURHIs, Richard. 1997. Linguistic Landscape and Ethnolinguistic Vitality: An Empirical Study. Journal of Language and Social Psychology 16(1), 23-49.

MATúšová, Jana. 2007. Benátky. In: Slovník pomistních jmen v Čechách III. Praha: Academia, 84-85. 
Delimitative Function of Place Names in the Linguistic Landscape - as Illustrated with Examples ...

OlivovÁ-NezBedovÁ, Libuše. 2005. Amerika [America]. In: Slovník pomístních jmen v Čechách I. Praha: Academia, 52-53.

PleskalovÁ, Jana. 2017. Transonymizace [Transonymization]. In: Nový encyklopedickýslovník češtiny. Praha: Nakladatelství Lidové noviny, 1895.

ŠRÁMEK, Rudolf. 1999. Úvod do obecné onomastiky [Introduction into General Onomastics]. Brno: Masarykova univerzita.

ŠRÁMEK, Rudolf. 2003-2004. Transonymizace v propriální nominaci [Transonymization in Proper Names Creation]. Folia onomastica Croatica 12-13, 499-508.

ŠrŔ́MEK, Rudolf. 2019. Amerika [America]. In: Slovník pomístních jmen na Moravě a ve Slezsku [online]. Brno: dialektologické oddělení Ústavu pro jazyk český AV ČR, v. v. i. 2014. [Retrieved 2019-01-31]. Available at: http://spjms.ujc.cas.cz

Acknowledgement: This research was supported by the University of Ostrava's internal grant (SGS) project no. 02/FF/2018-2019 Vytváření reality prostřednictvím jazyka - kvalitativní analýza novočeských textů [Reality Creation through Language A Qualitative Analysis of Modern Czech Texts].

\section{Jaroslav David}

Department of Czech Language

Faculty of Arts, University of Ostrava

702 oo Ostrava, Czech Republic

jaroslav.david@osu.cz 